\title{
Public Perception of the Role of the Nigeria Police Force in Curbing the Menace of Kidnapping in Benin Metropolis, Southern Nigeria: A Criminological Study
}

\author{
Barr. Emmanuel Imuetinyan Obarisiagbon, Ph.D \\ Dept. of Sociology \& Anthropology, Faculty of Social Sciences \\ University Of Benin, Benin City, Edo State, Nigeria
}

\author{
Mannie Omagie \\ Department of Sociology, Benson Idahosa University, \\ Benin City-Edo State, Nigeria
}

Doi: 10.2478/ajis-2018-0006

\begin{abstract}
Kidnapping for ransom has been on the increase in the last ten years in Nigeria and there appears to be no end in sight despite the existence of a police force whose statutory function of crime detection and prevention has come under fire for its abysmal performance. This study therefore examined the public perception of the role of the Nigeria police force in curbing the menace of kidnapping in Benin Metropolis, Southern Nigeria. This study adopted the problem-oriented policing theory in its explanation of the topic under investigation. It also employed the survey and cross-sectional design. The quantitative technique was utilized to collect data from the respondents while a total of 960 respondents were quantitatively sampled. Both descriptive and inferential statistics were used to analyse the quantitative data collected from the field. Findings from this investigation showed that there is a very poor public perception of the police and that there are a multiplicity of obstacles hindering the efforts of the police at curbing the activities of kidnappers in Nigeria. Based on the findings of the study, it was recommended that government should improve the funding of the police to boost the morale of the rank and file while the police on its part should get rid of the bad elements within its system in order for public confidence to be restored in its ability
\end{abstract}

Keywords: Kidnapping, police, obstacles, public perception

\section{Introduction}

As a nation, Nigeria is presently battling not only with economic recession but also with security challenges. The country has and is still experiencing a high rate of criminal activities particularly, kidnapping. It was a relatively unheard of phenomenon until the year 2006 when it became popularized by the Niger Delta militants who seized and kept as hostage, foreign oil workers. In a bid to draw the world's attention to the deplorable socio-economic plight of inhabitants of the region as well as, its ecological and environmental degradation, the militants embarked on kidnapping. Kidnapping is the unlawful taking away of an individual without his consent and keeping the person in a confined place until a ransom is paid.

However, while the foreign oil workers were being kidnapped and ransom paid, the Nigeria Police Force could not rise to the occasion in terms of arresting the kidnappers, let alone prosecuting them. Little wonder therefore, that without any hindrance and deterrence, kidnapping 
spread like wild fire to other regions in the country, with the police watching helplessly as the victims' relations go scouting for money to pay the demanded ransom. It would appear that by the very nature of kidnapping, it tends to disrupt the social order and impinge on public security. In fact, the techniques and methods used to address this ugly development seem not to be yielding the desired result especially against the alarming rate of its incidence and prevalence. Ugwuoke (2011) notes with regret that the more the police try to strategize on ways and methods of tracking down the kidnappers, the more they unleash terror and mayhem on their victims and the society.

There is no doubt that the upsurge in kidnapping activities in Nigeria and the apparent inability of the police to live up to their statutory responsibilities of prevention and detection of crime, kidnapping inclusive, has far-reaching social implications on the citizenry. This is because, the upsurge in the crime of kidnapping not only remains the most disturbing and traumatizing experience to people but also has made people to live in perpetual fear and state of insecurity (llechukwu, Uchem and Asogwa, 2015).

\section{Statement of the Problem}

Unarguably, kidnapping remains one of the contemporary social menaces plaguing the Nigerian state today. Hardly does a week pass without the media going agog with the breaking news of the kidnap of a known person in the society. The situation has so much deteriorated that one wonders whether there are laws against its occurrence and if those charged with the maintenance of law and order and the prevention and detection of crime are still to be found in the Nigerian state. Granted that involvement in kidnapping is as a result of a multiplicity of factors ranging from poverty, the get rich quick syndrome, moral decadence, greed and unemployment (Inyang, 2009). Inyang and Ubong (2013) however point to the fact that the Nigeria Police Force lacks the resources to cope with kidnapping. In fact, the Nigeria Police Force has been severely lashed at for its inability to stem the upsurge in kidnapping in Nigeria, especially, due to the endemic problem in its recruitment, training, discipline and lack of expertise in specialized fields.

Ash (1971) opines that the performance of the Nigeria Police Force has been entirely dissatisfactory owing largely perhaps to the confusion in the minds of people as to what policemen actually do on the job and what they can reasonably be expected to do to achieve a more effective police force. In Nigeria, it would appear that the main work of the police is to attend to emergencies. Little attention is paid, if at all on crime prevention and without doubt, this has greatly accounted for the high incidence and prevalence of kidnapping in the country.

Some scholars like Obarisiagbon (2017) have contended that the reason for the rise in kidnapping is to be located at the corridor of the Nigeria Police Force. He notes just like Okarah (2014) that corruption and dishonesty are endemic among the rank and file of the police force. In fact, this twin evil- corruption and dishonesty account for the low level of public confidence in the ability of the police. Little wonder then, that the relations of the victims of kidnapping are often quick to pay the ransom rather than reporting the incidence to the police.

The kidnapping situation and the seemingly lack of willpower by the police to enforce the law seem to have made Nigerians resign to their fate. Questions which keep begging for answers include, how did we as a nation state get into this precarious and helpless situation? Is it not possible for public confidence to be restored in the Nigeria Police Force? These questions require urgent answers that the morale of officers and men can be boosted with the resultant security of lives and property.

\section{Objectives of the Study}

The general objective of this study was to:

1. Examine the obstacles confronting the police in relation to curbing kidnapping in Benin metropolis, southern Nigeria.

2. Determine if the public sees the police as effective in curbing kidnapping in Benin metropolis, southern Nigeria. 


\section{Research Questions}

1. What are the obstacles confronting the police in curbing kidnapping in Benin metropolis, southern Nigeria?

2. Does the public see the police as effective in curbing kidnapping in Benin metropolis, southern Nigeria?

\section{Brief Review of Related Literature}

Kidnapping as a social phenomenon, is a very serious crime but unfortunately, it is relatively unheard of in contemporary scholarship compared to stealing, armed robbery, rape and other forms of crime. Yang and Huang (2007) attribute the relative obscurity of kidnapping to three factors: rarity of the event itself, access to known kidnappers and data problem. The incidence and prevalence of the unlawful and nonconsensual taking of a person with the intent to demand for ransom before release can be made, is a crime punishable under section 364 of the Criminal Code (2004) with ten years imprisonment. Not too long ago, states like Edo, Delta and Anambra, believing that the alarming rate of kidnapping was due to what was termed mild punishment, made it an offence punishable by death by passing the appropriate bills into law. In spite of this, kidnapping is still on the increase. This has made scholars to turn their focus on the role and functions of the Nigeria police in crime detection and prevention.

The history of the first police force in Nigeria is traceable to 1861 and between 1867 and 1914 , other police forces were created to maintain what the colonialists felt was law and order (Alemika, 2003). Initially, two types of police system viz force and constabulary were set up and controlled by the colonial officials and the local forces which were controlled by the local traditional rulers. Tamuno (1970) notes that what is today referred to as the Nigeria police force is the amalgamation of the southern and northern police forces which was saddled with normal police duties as well as extra police functions. Today, the Nigeria police force has undergone organizations and reorganizations with the Police Act (2004) clearly stating the functions as prevention and detection of crime, protection of lives and property of citizens, maintenance of law and order in the society, investigation of matters pertaining to crime and arrest, and prosecution of offenders in the law court (Police Act, 2004).

\section{Obstacles Confronting the Nigeria Police Force in Curbing Kidnapping}

Scholars have attested to the fact that there is much to be desired in the effectiveness and efficiency of the Nigeria police force in relation to combating crimes. Till date as Odekunle (2014) observed, despite the enabling statutory backing that the police has, it has rather displayed and generated a great deal of controversies with regards to the maintenance of public peace, safety, security and crime prevention and detection. Various factors have been blamed as constituting challenges to effective and efficient policing in Nigeria. In fact, these challenges are cumulative and range from material to human and external.

One of the major obstacles which greatly hinder the police in its effort to curb kidnapping in Nigeria is the widespread corruption among its rank and file (officers and men). The stigma of corruption in the Nigeria police force is damning and includes the taking of bribe from suspects as well as complainants before carrying out its statutory functions. Despite the efforts of the police to counter the corruption tag that has stuck firmly on its image, Alemika (1999) asserts that the issue of corruption in the police force is an undeniable fact with several evidence of their involvement. Obarisiagbon (2017) further attested to the fact that the police connives with kidnapping offenders to help them out of police custody after collecting money from them and their relations and subsequently closing the case file or writing a report in favour of the offender.

Closely associated with the label of corruption that has been placed on the Nigeria police force is the poor perception the public has of it. The cankerworm of corruption has deeply affected the social image of the public as public opinion regarding the integrity of police officers is that of "dirty Harry" (Onyeozili, 2005). In his study, Ugwulebo (2011) notes that the police force has been 
criticized for aiding and abetting kidnappers, resulting in the public being unwilling to report incidence of the crime to the police. Rather, they prefer to pay the ransom to the kidnappers so that their relations or friends can regain their freedom. This very low public attitude towards the

Nigeria police force is also a consequence of a historical legacy of using the police to suppress Nigerians by the colonial and post-colonial governments (Alemika and Chukwuma, 2000). Regrettably, the public has therefore become unwilling to cooperate with the police in crime prevention and detection. Interestingly, without the needed information and cooperation of the public, the police cannot do much in the maintenance of security.

Inadequate training, materials and poor remuneration for both officers and men of the Nigeria police force are notable factors that have created abysmal performance for the police in carrying out their statutory functions of crime prevention and detection. The training of policemen is a sine qua non to effective performance but regrettably, there is little or none presently and where any exist, it is very poor as the men are not thoroughly exposed to modern policing (Adegoke, 2014). Besides, there is a paucity of equipment. The few ones which are available are obsolete, crying for replacement and yet have none in sight. A major equipment that has handicapped the police in its quest to curb kidnapping in Nigeria, is its lack of tracking devices and as such, they are not able to track down kidnappers. To worsen the situation is the very uncooperative attitude of the GSM operators who are either unwilling to give call details of suspected kidnappers or claim that their equipment is faulty (Obarisiagbon, 2017). This unwholesome situation has greatly impacted on the performance of the police in relation to the curbing of kidnapping.

The saying, "a hungry man is an angry man" plays out very well in the performance of the police. The salary of the average police is nothing compared with that of the politicians and their contemporaries in other parastatals. The welfare is quite inadequate and there is no motivation from the government and any other quarter. The policeman puts his life on the line when chasing kidnappers and other criminals, gets hurt and in some cases killed with no insurance scheme or provision for his wife, children and dependents. Such a situation leads to apathy, indifferences and unwillingness to put in one's best in the service to the nation.

Agreed that generally, Nigeria is still witnessing the effect of economic recession, and there has been the underfunding of government agencies, it has however remained a recurring decimal in the annals of the Nigeria police force. The various barracks across the country need a facelift, the police colleges are in a sorry state, equipment and materials are constantly unavailable or in short supply. Orobator (1993) has maintained that cases of an entire police division having only one police van which in some cases is not serviceable or an entire station not having at all abounds. These issues remain unsolved without adequate funding; the state of preparedness of the police to carry out its constitutional functions of prevention and detection of crime particularly the now very attractive kidnapping is near zero especially as coordination of their activities is made more difficult. It is therefore glaring from the preceding paragraph that the conclusions which many scholars have reached with regards to the fact that the police has a bad image in the eye of the public as well as that it is most inefficient and effective in curbing crimes, kidnapping inclusive is not far from the truth (Odekunle, 2004; Asegoke,2014).

\section{Theoretical Framework}

This study adopted the problem-oriented policing theory in its explanation of the topic under investigation. This theory was first introduced by Goldstein (1979) and popularized by Eck and Spelman (1987). The theory is typically defined as focusing police attention on the underlying causes of problems behind a string of crime incidents. The police spend too much time focusing on issues bothering on staffing and management of policing rather than the problems policing was designed to solve and so, in Goldstein's (1979) opinion, this disconnect was the bane of police inability to effectively tackle crime. He therefore called for a paradigm shift that would require the police to be proactive in identifying crimes.

Building on Goldstein's (1979) postulations, Eck and Spelman (1987) developed the SARA model for problem solving. SARA simply put, is an acronym representing four steps that the police should adopt when implementing problem-oriented policing. In using this model, the police should 
first do a scanning which involves the identification and prioritization of potential problems that may be causing crime in a particular location. Thereafter, an analysis should be done. In other words, the police should analyse the problems earlier identified so as to develop the right responses. The third and fourth steps involve the police's response by developing and implementing interventions aimed at solving the problems and carrying out an assessment of the impact of the response on the targeted problems.

In relation to the study under focus, it is believed that the police, if it jettisons reactiveness and adopts proactiveness by adopting the SARA model, it will be in a better position to curb the social menace of kidnapping in Benin metropolis. This view is given credence to by the fact that research findings indicate that problem-oriented policing can indeed reduce the fear of crime, violent and property crime and thefts (Cordner, 1986 and Weisburd and Green, 1995).

\section{Methods and Materials}

The study is descriptive in nature, employing a cross sectional design. The design is appropriate to this study because it sought to describe and study in depth, public perception of the role of the police in curbing the social menace of kidnapping. It also, satisfies scientific curiosity and improves our understanding of the unit of analysis. Being a single time frame study, a cross section of the population made up of the adults, legal practitioners and kidnap victims and their relations was studied at one point in time. The study was conducted in the Benin metropolis which is made up of twelve quarters/wards. The choice of Benin metropolis was due to the high incidence and prevalence of the topic under study.

A public perception of police role questionnaire (PPPRQ) was designed to collect all important information needed to achieve the objective of this study. 28 different questions were included in the questionnaire and arranged in two sections as follows:

* The first section refers to the demographic characteristics of respondents including age, educational level, sex and religion.

* The second section consists of 24 questions measuring police and efforts at curbing kidnapping.

The face and content validity of the research instrument was ascertained by three experts in the field of education and sociology in the University of Benin, Nigeria. The research instrument was divided into two sections. Section A dealt with the demographic characteristics of respondents while section $B$ dealt primarily with the issues involved in the subject under inquiry. The split-half method was used to determine the reliability of the instrument. Reliability coefficient result obtained for the instrument was 0.95 . The descriptive and inferential statistics were used to analyse the quantitative data collected from the field.

The stratified sampling technique was used to select respondents equally from the population of study while the simple random sampling method was employed to select the final element from the population.

Out of the nine hundred and sixty (960) questionnaires that were administered to the respondents, nine hundred and forty-two (942) were returned, found useful and therefore used for analysis. This however represents a return rate of $98.1 \%$ and is considered significant. For the purpose of efficiency and thoroughness, three field assistants due to the sample size were recruited and trained. The field assistants were involved in the pre-test of the instruments and also the collection of the required data used for the study

Table 1: Demographic characteristics of respondents

\begin{tabular}{|l|l|l|}
\hline & Frequency & Percentage (\%) \\
\hline Sex & & \\
\hline Male & 679 & 70 \\
\hline Female & 236 & 30 \\
\hline Total & $\mathbf{9 4 2}$ & $\mathbf{1 0 0}$ \\
\hline & & \\
\hline
\end{tabular}




\begin{tabular}{|l|l|l|}
\hline & Frequency & Percentage (\%) \\
\hline Age & & \\
\hline $18-30$ & 125 & 3 \\
\hline $31-40$ & 480 & 51 \\
\hline $41-50$ & 275 & 29 \\
\hline Above 50 & 62 & 7 \\
\hline Total & $\mathbf{9 4 2}$ & $\mathbf{1 0 0}$ \\
\hline Educational level & & \\
\hline Secondary & 232 & 24 \\
\hline Tertiary & 484 & 51 \\
\hline Primary & 248 & 26 \\
\hline Total & $\mathbf{9 4 2}$ & $\mathbf{1 0 0}$ \\
\hline Religion & & \\
\hline Christianity & 913 & 97 \\
\hline Islam & 4 & 0.4 \\
\hline ATR & 25 & 2.6 \\
\hline Total & $\mathbf{9 4 2}$ & $\mathbf{1 0 0}$ \\
\hline
\end{tabular}

Source: field survey, 2017

Table 1 summarizes the results of the demographic characteristics of the respondents. It shows that among the 942 respondents who participated in the study, $70 \%$ of them were male while $30 \%$ were female. $3 \%$ were in the $18-30$ years age range, $51 \%$ were between $31-40$ years while $29 \%$ were between $41-50$ years and $7 \%$ were 50 years and above. On educational level, $24 \%$ of the respondents had secondary education, $51 \%$ had tertiary education while $26 \%$ had primary education. On religious affiliation, $97 \%$ of the respondents were Christians, $0.4 \%$ were Muslims and $2.6 \%$ practiced African Traditional Religion.

Table 2: Obstacles to effective detection and prevention of kidnapping by the Nigeria police

\begin{tabular}{|l|c|c|}
\hline & Frequency & Percentage (\%) \\
\hline Corruption & 124 & 13 \\
\hline Poor public perception & 193 & 20 \\
\hline Inadequate training, equipment and motivation & 137 & 15 \\
\hline Uncooperative attitude of GSM operators & 93 & 10 \\
\hline All reasons stated above & 395 & 42 \\
\hline Total & $\mathbf{9 4 2}$ & $\mathbf{1 0 0}$ \\
\hline
\end{tabular}

Source: field survey, 2017

Table 2 reveals that $13 \%$ of the surveyed population believed that corruption is an obstacle to effective detection and prevention of kidnapping by the Nigeria police, $20 \%$ held on to poor public perception while inadequate training, equipment and motivation had $15 \% .10 \%$ was for uncooperative attitude of GSM operators and 395\% for all reasons stated above.

The finding of this study further validates the works of Obarisiagbon (2017), Adegoke (2014) and Odekunle (2014) who contended that the above factors are obstacles to effective detection and prevention of kidnapping in Nigeria.

Table 3: Public perception of the role of the Nigeria police force in curbing the menace of kidnapping

\begin{tabular}{|l|c|c|}
\hline Do you think that the police is effective in curbing kidnapping? & Frequency & Percentage (\%) \\
\hline No & 891 & 95 \\
\hline Yes & 51 & 5 \\
\hline Undecided & - & - \\
\hline Total & $\mathbf{9 4 2}$ & $\mathbf{1 0 0}$ \\
\hline
\end{tabular}

Source: field survey, 2017 
Results from table 3 indicates that $95 \%$ of the surveyed population disagreed that the police is affirmed effective in curbing kidnapping, only $5 \%$ affirmed that the police is effective in curbing kidnapping while there were no undecided respondents.

This study's finding agrees with the works of Odekunle (2014) and Onyeozili (2005) who have argued that public perception of the police is very low due to their abysmal performance oat curbing crime, kidnapping inclusive.

\section{Conclusion and Recommendations}

This study examined the public perception of the role of the Nigeria police force in curbing kidnapping in Benin metropolis. The study revealed that kidnapping is a social menace that is currently spreading like wild fire with its near daily occurrence in spite of the laws against its commission. The study found that the ability of the police force to live up to the expectation in terms of carrying out its statutory responsibilities is largely due to the alarming incidence and prevalence of kidnapping. The study concludes that the dismal performance of the Nigeria police force with regards to curbing this social phenomenon is linked to the several cumulative obstacles that range from material to human and external challenges, notably amongst which are corruption, poor public perception, uncooperative attitude of GSM operators and inadequate training of men and officers of the police. Based on these findings, the following recommendations are made:

* The police should put machinery in place to rid itself of bad elements within the system that have soiled the image of the police with extortion, demanding and taking of bribe from the public.

* The Police should also embark on the laundering of its image by rebranding. The media can readily be used in this direction, if it genuinely desires a better image and service delivery.

* There is the need for government to be alive to its responsibility of adequately funding the police, instead of paying lip service to their welfare. In this direction, there should be training and retraining of officers and men of the police in line with modern dictates. Besides, modern equipment including tracking devices and forensic laboratories should be acquired to ease the work of the police in relation to curbing kidnapping activities. While efforts should be made to enhance the living wages of the police personnel as what they presently take home as salary is grossly inadequate.

\section{References}

Adegoke; N. (2014) The Nigeria Police and the challenges of security in Nigeria. Review of public administration and management. Volume 3 No 6. pp 21-36

Alemika, E. E. O. 1988. Policing and perception of police in Nigeria. Police Studies 11(4): 161-176.

Alemika, E. and Chukwuma, I. 2000. Police community violence in Nigeria. Lagos, Center for Law Enforcement Education and National Human Rights Commission.

Alemika, E.E.O.2003. The politics of identities and democracy in Nigeria, Jos: University of Jos.

Ash, H.S (1971), Police authority and rights of individual .Arco Publishing comp, New York, U.S.A.

Cordner, G (1986) Fear of crime and the police: An evaluation of fear reduction strategy. Found of police science and Administration 14(3) 223-233

Criminal Code Act, Cap C 38 Laws of the Federation of Nigeria. 2004

Eck, J.E. \& Spelman, W. 1987, Problem Solving: Problem-Oriented Policing in Newport News, National Institute of Justice, United States Department of Justice, Washington DC.

Goldstein, H. 1979, "Improving policing: A problem-oriented approach", Crime and Delinquency, vol. 25, no. 2, pp. 236-58.

Illechukwu, L.C., Uchem, R.N. and Asogwa, U.D. 2014. Stemming the incidence of kidnapping in the Nigerian society. Journal of Culture, Society and Development Vol. 12 pp 28-47

Inyang, J. D. 2009. Kidnapping: who can deliver Nigeria? News D'or Magazine. Vol. 1 (a): July 12 p11-15

Inyang, J. D. and Ubong, E. A. (2013). "The Social Problem of Kidnapping and Its Implications on the SocioEconomic Development of Nigeria: A Study of Uyo Metropolis". Mediterranean Journal of Social Sciences. Vol. 4 No. 6, pp

Obarisiagbon, E.I. (2017). Kidnapping and the administration of criminal justice in selected states in Nigeria. 
Unpublished Ph.D dissertation, University of Ibadan, Ibadan, Nigeria.

Odekunle, F. 2004. Overview of policing in Nigeria: problems and suggestions. Ikeja-Lagos: Cleen foundation.

Okarah, C.I (2014) Cause of insecurity in Nigeria: The challenges and relevance of the Nigeria Police Force as a panacea. Unpublished M.sc Thesis, University of Nsukka.

Onyeozili, E.C. (2005) Obstacles To Effective Policing In Nigeria, African Journal Of African Journal of Criminology and Justice Studies. Vol. 1, No. 1.

Orobator, S.E. 1993. The political and socio-economic environment of policing since 1960. Policing Nigeria past, present and future. T. N. Tamuno; I.L Bashir; E.E.O. Alemika. and A.O. Akano Eds. Lagos: Malthouse Press Ltd.

Police Act Laws of the Federation of Nigeria, 2004

Tamuno, T.N. 1970. Police in Modern Nigeria 1861-1965. Ibadan: University of Ibadan Press.

Ugwulebo, O.E. 2011. Kidnapping in Nigeria. Enugu. Cel-Bez Publishing Co. Ltd

Ugwuoke, C.U. (2011). Nigeria and the Menace of Kidnapping: The Way Forward. The Nigerian Journal of Research and Production Vol.18 pp.44-57.

Weisburd, D. \& Green, L. 1995, "Policing drug hot spots: The Jersey City Market Analysis Experiment”, Justice Quarterly, vol. 12, no. 4, pp. 711-35.

Yang, S L SL Huang, S.L(2007) Kwanppi - Taiwan, the significance of geographic proximity improvisation and fluidity International Journal of Offenders 51(3) 324-3G 